\title{
Negative policy interest rates and exchange rate behavior: further results ***
}

Professor John Thornton

The Business School, Bangor University, College Road, Bangor LL57 2DG, UK; and

US Department of the Treasury, Office of Technical Assistance, Washington DC, USA. Email:

John.Thornton@otatreas.us; j.thornton@bangor.ac.uk

Dr. Chrysovalantis Vasilakis (corresponding author)

The Business School, Bangor University, College Road, Bangor LL57 2DG, UK; and Institut de Recherches Economiques et Social, Université Catholique de Louvain, Louvain, Belgium. Email : c.vasilakis@bangor.ac.uk

\begin{abstract}
:
Since 2012, seven central banks sought have additional monetary policy accommodation through the adoption of negative policy interest rates (NPIR). The policy resulted in a significant reduction in exchange rate volatility and weaker exchange rates in NIRP-adopter countries relative countries that did not adopt the policy.

JEL: E52, F31, G15

Keywords: Negative policy interest rates, exchange rate behavior, difference in difference estimation

${ }^{*}$ We are grateful to an anonymous referee whose comments and suggestions improved the paper.

** The views expressed in this paper are those of the authors and do not represent the views of the organizations they represent.
\end{abstract}

Negative policy interest rates and exchange rate behavior: further results 


\section{Introduction}

Many central banks responded initially to the of 2008-09 global financial crisis by reducing policy interest rates sharply. When this failed to bring about the hoped-for recovery in nominal spending, several of them experimented with unconventional monetary policies (UMP), including largescale asset purchases to raise asset prices and increase the supply of bank reserves, targeted asset purchases to alter the relative prices of different assets, and forward guidance to the public as to the future policy interest rate path. Though the empirical evidence is mixed, it is probably fair to say that the impact of these policies on nominal spending was disappointing, which lead many central banks to consider further policy measures. ${ }^{1}$ From 2012, seven central banks - the European Central Bank and the central banks of Denmark, Hungary, Norway, Sweden, Switzerland, and Japan — sought additional monetary policy accommodation by broadening the scope of UMP to include negative policy interest rates (NPIR). The policy has been controversial: though most of the NPIR-adopter central banks gave their primary motivations for the policy as the stabilization of inflation expectations and supporting economic growth (Jobst and Lin 2016), many commentators viewed it as an intensification of a 'currency war' aimed at boosting export growth through exchange rate depreciation. ${ }^{2}$ Empirical evidence as to the impact of NPIR on exchange rates is scant, however. For example, Ball et al. (2016) survey recent developments in the monetary

\footnotetext{
${ }^{1}$ See Bhattarai and Neely (2016) for survey of the empirical literature of the effects of UMP in the US.

${ }^{2}$ For a flavor of the debate, see for example, Jonathan Wheetley and Peter Graham, "Brazil in 'currency war' alert", Financial Times, September 27, 2010; Shefali Anand and John Hilsenrath, "India's central banker lobbies Fed", Wall Street Journal, October 13, 2-13; Claire Jones, "Bundesbank chief rejects 'absurd' claim of euro manipulation", Financial Times, February 7, 2016; The Economist, "The phony currency wars", February 16, 2016; and John Plender, "Currency wars backfire for Japan and Europe", Financial Times, April 15, 2016.
} 
policy transmission mechanism in NPIR-adopter countries and conclude that exchange rate appreciation pressures were generally reduced and that the policy has been associated with an improvement in overall financial conditions and a modest expansion of credit in the euro area. Arteta et al. (2016) suggest that the impact of NPIR on exchange rates has been more varied with currencies depreciating on average against the U.S. dollar and on trade-weighted-terms, except for the Japanese yen and the Swiss franc. Jobst and Lin (2016) report that negative policy rates have had a muted impact on exchange rates as disinflationary dynamics in many countries with negative rates prevented real rates from declining further. Molyneux et al. (2017) focus exclusively on the impact of NPIR on bank lending and report that the policy resulted in weaker lending in NPIRadopter countries relative to others, probably because it undermined bank profitability. More related to our study, Hameed and Rose (2016) employ a gravity model to examine how NPIR has impacted on exchange rate volatility, exchange rate changes, deviations from uncovered interest parity, and profits from carry trade; they report that the policy appears to have had little effect on observable exchange rate behavior. In this paper, we provide further empirical evidence on the currency war debate by examining whether NPIR has had positive exchange rate effects in adopter countries employing a panel of daily and monthly exchange rates for 32 countries and a differencein-difference methodology. We find that NPIR resulted in a significant reduction in exchange rate volatility and in weaker exchange rates in NPIR-adopter countries relative countries that did not adopt the policy.

\section{Methodology and data}


We examine the impact of NPIR on exchange rate behavior using a difference-in-difference equation of the following form:

$$
F X_{i t}=\beta_{0}+\beta_{1} \text { Post }_{t}+\beta_{2}\left(T_{i} * \text { Post }_{t}\right)+\delta X_{i t}+\varepsilon_{i t}
$$

where $F X_{t}$ is the exchange rate variable in country $i$ at time $t, T_{i}$ is a dummy variable equal to 1 if the country is in the treatment group (i.e., the country is an NPIR-adopter), 0 otherwise, and captures possible differences between the treatment and control groups prior to the policy change; Post $_{t}$ is a dummy variable equal to 1 in the post-NPIR adoption period in either the treatment or control group of countries and captures aggregate factors that would cause changes in exchange rate behavior even in the absence of a policy change; $\left(T_{i} *\right.$ Post $\left._{t}\right)$ is the difference-in-difference estimator that captures the difference in average exchange rate behavior between the treated and control groups, and $X_{i t}$ is a control vector. $F X_{i t}$ is represented alternately by the volatility of the bilateral exchange rate, the natural logarithm of the level of the bilateral exchange rate, the volatility of the nominal effective exchange rate index, and the natural logarithm of the levels of the nominal and real effective exchange rate indices. In $X_{i t}$ we control for the influence of other unconventional monetary policies on exchange rates represented by the growth of central bank assets, which reflects the dominance of extensive outright asset purchases aimed at expanding the central bank's balance sheet as the main tool of UMP, and a newspaper-based economic policy uncertainty index measure.

As the European Central Bank was an early adopter of NPIR, and the euro zone comprised the largest "economy" to adopt the policy, the euro is the base currency for the analysis of developments in bilateral exchange rates, with exchange rates expressed in units of foreign 
currency per euro. The sample period spans January 2010 to March 2017 and covers 32 highincome and middle-income economies, seven of which adopted NPIR. The countries in the sample are listed in the Appendix. The sample begins in 2010 to reduce the after-effects of the global financial crisis and associated recession, while including a period of comparable data before the onset of negative interest rates. Data on policy interest rates, daily and monthly bilateral exchange rates, and central bank assets are from the different central bank websites; nominal effective exchange rate indices and monthly real and nominal effective exchange rate indices are from the Bank for International Settlements. The monthly volatility of the bilateral and nominal effective exchange rates is measured by the standard deviation of the daily percent change in the exchange rate or index. The economic policy uncertainty measure is provided by Baker et al. (2016). ${ }^{3}$ Developments in the key central bank policy rates are shown in Figure 1 and the dates of NPIR adoption and the motivations of each central bank for adopting the policy are provided in Table $1 .{ }^{4}$

\section{Empirical results}

Prior the estimation of equation (1), we check (but do not report) the stationarity of the variables using the panel unit root test suggested by Levin et al. (2002), and we test for cross-sectional dependence using the Pesaran (2004) cross-sectional dependence (CD) test. We find that for each variable the null hypothesis that the panels contain a unit root is rejected, whereas the null

\footnotetext{
${ }^{3}$ These series can be downloaded from: http://www.policyuncertainty.com/. In the case of the individual European countries in our sample for which separate series are not available, we have used the authors European Policy Uncertainty index and for the non-European countries for which individual series are not available, we have used the authors' Global Policy Uncertainty index.

${ }^{4}$ See Bech and Malkhozov (2015) for a discussion of the implementation mechanisms of NPIR in the adopting countries.
} 
hypothesis of cross-section independence is not rejected. ${ }^{5}$ In Table 2, we report estimates of equation (1) for monthly exchange rate volatility and the level of the bilateral exchange rate. In column 1 the coefficient on the Post dummy variable indicates that exchange rate volatility increased through time while the coefficient on $T^{*}$ Post shows that relative to the control group, average exchange rate variability fell sharply in the NPIR adopter countries relative to that in the non-adopters; the average treatment effect is equivalent to an $13 \%$ decrease. Column 2 reports the results for the level of bilateral exchange rate. The bilateral exchange rates of these countries generally depreciated through time but the coefficient on $T^{*}$ Post indicates that the exchange rates of the NPIR-adopters depreciated by $3.9 \%$ more on average relative to those of non-adopters. The estimates reported in columns 3 and 4 drop Norway and Hungary from the treatment group as these countries only adopted NPIR very late in the sample period. The results from this sample also suggest less exchange rate volatility $(9.1 \%)$ and even more bilateral exchange rate depreciation (12.2\%) for NIRP adopters. As regards the control variables, the growth of central bank assets appears to have been associated with a modest increase in exchange rate variability and an appreciation in bilateral exchange rates, while the policy uncertainty index appears to have had a modest positive impact.

Table 3 reports estimates of equation (1) for the monthly volatility of the nominal effective exchange rate index and for the levels of the monthly nominal and real effective exchange indices. The NPIR adopters appear to have had a markedly different exchange rate experience on these measures also. The results in panel (a) include all six NPIR adopters in the treatment group. The volatility of the nominal effective exchange rate and its level fell sharply for the NPIR-adopters

\footnotetext{
${ }^{5}$ The results of these tests are available on request.
} 
relative to the other countries ( $11.8 \%$ and $6.8 \%$, respectively). In contrast, NPIR adoption does not seem to have been associated with any relative change in the real effective exchange rate for NPIRadopters. In panel (b) we drop Norway and Hungary from the estimates. These results also indicate that NPIR-adopters experienced relatively less volatility and relatively more depreciation of the nominal effective exchange rate, but no statistically significant difference in the behavior of their real effective exchange rates.

We subject our results to two robustness tests. First, we estimate equation (1) for dollar-based bilateral exchange rate volatility and exchange rate levels to ensure that the currency base has not distorted the results. These estimates are reported in Table 4. The general conclusions do not change: NPIR adopter countries also experienced less bilateral nominal exchange rate volatility and greater bilateral exchange rate depreciation when the dollar is the currency base. Our second robustness test is more substantial. Equation (1) gives rise to an important econometric issue in evaluating the effect of NPIR when the decision to adopt the policy is not random. If NPIR adoption is systematically correlated with a set of variables that also affect the outcomes, then we will have the selection on variables problem, which makes linear regression with an NPIR adoption dummy an unreliable method. ${ }^{6}$ To address the self-selection problem, we make use of four propensity score matching methods that have been developed in the treatment effect literature and have been applied recently in applied economics (Glick et al., 2006; Lin and Ye 2007, 2009, 2010, 2013; Thornton and Vasilakis, 2017). The first method is nearest-neighbor matching with replacement, which matches each treated country to the $\mathrm{n}$ control countries that have the closest propensity scores. We use two nearest-neighbor matching estimators: $n=1$ and $n=3$. The second method is radius matching, which performs the matching based on estimated propensity scores

\footnotetext{
${ }^{6}$ Dehejia and Wahba (2002) and Heckman et al. (1998) provide detailed discussions.
} 
falling with a certain radius $\mathrm{R}$. We use a wide radius $(r=0.05)$, a medium radius $(r=0.03)$, and a tight radius $(r=0.01)$. The third method is the kernel matching method, which matches a treated group country to all control group countries weighted in proportion to the closeness between the treated group country and the control group country. The final method is the regression adjusted local linear matching method developed by Heckman et al. (1998).

We first use the following probit model to estimate the propensity scores, which are the probabilities of adopting a NPIR policy conditional on a group of control variables:

$$
P\left(Y_{i t}=1 \mid X_{i t}\right)=\Phi\left(X_{i t}^{\prime} \beta\right)+\eta_{i t}
$$

where $Y_{i t}$ is a dummy variable for the adoption of NPIR, $X_{i t}^{\prime}$ is a set of control variables, $\Phi$ is the cumulative function of the standard normal distribution, and $\eta_{i t}$ is the error term. We then utilize the estimated propensity scores to conduct matching to obtain the treatment effects of NPIR adoption (compared to those of non-NPIR adoption). For the control variables, the limited NPIR literature discussed above suggests that the probability of a country adopting a NPIR is likely to be greater if it has a low level of inflation and a high rate of unemployment. In addition, the policy would seem more likely to be adopted by countries that had a relatively flexible rate regime and if the central bank was relatively independent. Accordingly, we include in our baseline probit estimation: the rate of consumer price inflation, the rate of unemployment, the relative flexibility of the exchange rate regime, and an index of central bank independence. ${ }^{7}$

\footnotetext{
${ }^{7}$ The index of central bank independence is from Dincer and Eichengreen (2014); the exchange rate classification scheme is the "coarse" classification devised by Reinhart and Rogoff (2004), which ranges from1 (most fixed) to 5 (most free). The annual classifications were updated by Ilzetzki et al. (2008) and the classifications relate to those in place in 2010.
} 
The probit results are reported in the columns (1) and (2) of Table $5 .{ }^{8}$ Broadly, the probability of a country adopting negative policy interest rates is greater if inflation is low, the exchange rate regime is more flexible, and the central bank is more independent; though contrary to what we would expect, the rate of unemployment appears to be negatively associated with the likelihood of NPIR adoption. The estimated average treatment effect on the treated (ATTs) for the measures of exchange rate behavior are reported in Table 6 . The results are a further indication that NPIRadopters reaped positive benefits from the policy, experiencing less exchange rate volatility and greater exchange rate depreciation relative to countries that did not adopt NPIR. In all cases, the ATTs are negative and in most they are highly statistically significant and quite large in magnitude. For example, for NPIR adopters bilateral exchange rate volatility and the bilateral exchange rate level (rows 1 and 2 of Table 6) fell between $11.5-33 \%$ and 10-62\%, respectively, relative to the experience of non-adopters. ${ }^{9}$ Thus, NPIR adoption appears to have been associated with statistically significant and quite large positive effects on exchange rate volatility and exchange rate levels.

\section{Conclusions}

From 2012, seven central banks sought additional monetary policy accommodation through the adoption of negative policy interest rates, a policy that several commentators and policymakers viewed as an intensification of the "currency war." Our results employing a panel of daily and

\footnotetext{
${ }^{8}$ The sample of countries falls to 20 for the probit and propensity score matching analysis because of data constraints.

${ }^{9}$ We also estimated, but do not report, ATTs for dollar based bilateral exchange rates; these results are similar to the euro-based estimates.
} 
monthly exchange rates and a difference-in-difference methodology indicate that the policy benefited NPIR-adopters in terms less exchange rate volatility and more depreciated exchange rates relative to countries that did not adopt the policy. Accordingly, NPIR can be beneficial provided most trading partners do not adopt the same policy and that adopter countries are prepared to face opprobrium of their trading partners and the risk that they will retaliate. 


\section{References}

Arteta, C, Kose, M.A., Stocker, M., Taskin, T., 2016. Negative interest rate policies: sources and implications. CEPR Discussion Paper No.11433.

Baker, S.R., Bloom, N., Davis, S.J., 2016. Measuring Economic Policy Uncertainty. The Quarterly Journal of Economics 131, 1593-1636.

Ball, L., Gagnon, J., Honohan, P., Krogstrup, S., 2016. What else can central bank do? Geneva Reports on the World Economy 18, ICMB and CEPR.

Bech, M., Malkhozov, A., 2015. How have central banks implemented negative policy rates? BIS Quarterly Review (March), 31-44.

Bhattarai, S., Neely, C., 2016. A survey of the empirical literature on US unconventional monetary policy. Federal Reserve Bank of St. Louis Working Paper 2016-021A.

Dehejia, R.H., Wahba, S., 2002. Propensity score-matching methods for nonexperimental causal studies. Review of Economics and Statistics 84, 151-161.

Dincer, N.N., and Eichengreen, B., 2014. Central bank transparency and independence: updates and new measures. International Journal of Central Banking 10, 189-253.

Glick, R., Guo, X., Hutchinson, M., 2006. Currency crises, capital account liberalization, and selection bias. Review of Economics and Statistics 88, 2006, 698-714.

Hameed, A., Rose, A.K., 2016. Exchange rate behavior with negative interest rates: some early negative observations. CEPR Discussion Paper 11498.

Heckman, J., Ichimura, H., Todd, E., 1998. Matching as an econometric evaluation estimator. Review of Economic Studies 65, 1998, 261-294. 
Ilzetzki, E., C. Reinhart, Rogoff, K.S., 2008. Exchange rate arrangements entering the $21^{\text {st }}$ century: which anchor will hold? Unpublished manuscript, University of Maryland and Harvard University, 2008.

Jobst, A., Lin, H., 2016. Negative interest rate policy (NIRP): implications for monetary transmission and bank profitability in the euro area. IMF Working Paper No. 16/172.

Levin, A., Lin, C-F., Chu, C-S. 2002. Unit root tests in panel data: Asymptotic and finite-sample properties. Journal of Econometrics 108, 1-24.

Lin, S., Ye, H., 2007. Does inflation targeting really make a difference? Evaluating the treatment effect of inflation targeting in seven industrial countries. Journal Monetary Economics 54, 2521-2533.

Lin, S., Ye, H., 2009. Does inflation targeting make a difference in developing countries? Journal of Development Economics 89, 118-123.

Lin, S., Ye, H., 2010. Dollarization does promote trade. Journal of International Money and Finance, 29, 1124-1130.

Lin, S., Ye, H., 2013. Does inflation targeting help reduce dollarization? Journal of Money, Credit and Banking 45, 1253-1274.

Molyneuux, P., Reghezza, A., Thornton, J., Ru, X., 2017. Did negative interest rates impact on bank lending? Bangor Business School Working Paper 17/02.

Pesaran, M. H., 2004. General diagnostic tests for cross section dependence in panels. CESifo Working Paper No. 1229.

Reinhart, C. M., Rogoff, K.S., 2004. The modern history of exchange rate arrangements: reinterpretation. Quarterly Journal of Economics, 119(1), 2004, 1- 48. 
Thornton, J., Vasilakis, C., 2018. Fiscal rules and government borrowing costs: international evidence. Economic Inquiry 56, 446-459. 
Figure 1. Effective Central Bank Policy Interest Rates, 2010-2017

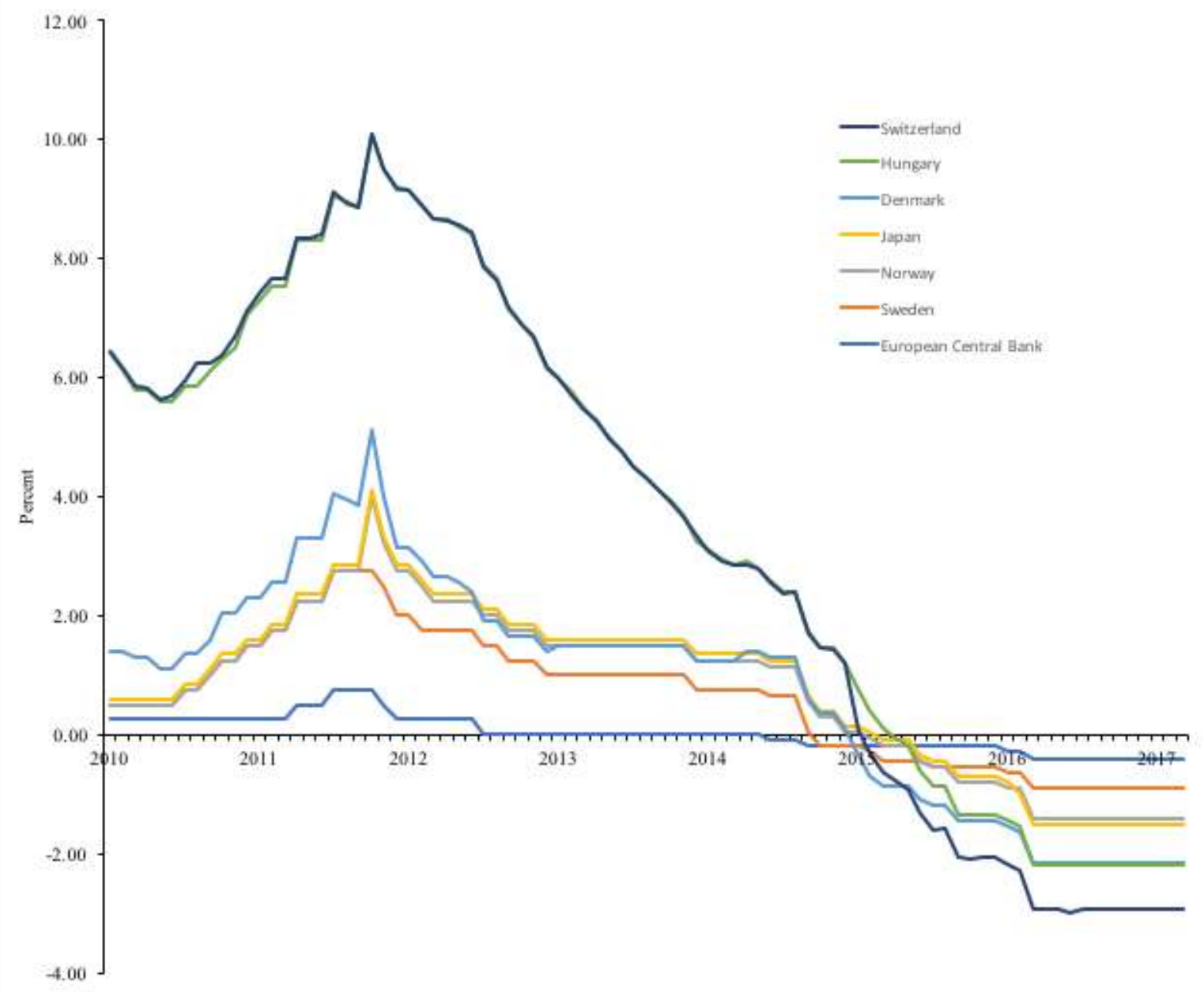

Sources: National central banks.

Notes: The central bank deposit rate refers to the rate on central bank current accounts beyond exemptions in Denmark, Japan, Norway, and Switzerland, and the rate on central bank deposit facilities in the euro area countries, Sweden and Hungary. 
Table 1

Overview of central banks with negative interest rate policy (NIRP)

\begin{tabular}{lll}
\hline Country & Date NIRP introduced & Objective \\
\hline Denmark & July 2012 & $\begin{array}{l}\text { Counter exchange rate } \\
\text { appreciation pressure }\end{array}$ \\
Euro area & June 2014 & $\begin{array}{l}\text { Price stability and } \\
\text { anchoring inflation } \\
\text { expectations } \\
\text { Price stability and } \\
\text { counter exchange rate } \\
\text { appreciation pressures }\end{array}$ \\
Japan & March 2014 & $\begin{array}{l}\text { Price stability and } \\
\text { anchoring inflation } \\
\text { expectations } \\
\text { Price stability }\end{array}$ \\
Norway & February 2016 & \\
Sweden & September 2015 & $\begin{array}{l}\text { Price stability and } \\
\text { anchoring inflation } \\
\text { expectations } \\
\text { Counter exchange rate } \\
\text { appreciation pressure }\end{array}$ \\
& &
\end{tabular}

Sources: National central banks; Jobst and Lin (2016). 
Table 2

Panel fixed effects results for bilateral exchange rates (euro-based)

\begin{tabular}{|c|c|c|c|c|}
\hline \multirow[b]{2}{*}{ Dependent variable: } & \multicolumn{2}{|c|}{ All NIRP adopters } & \multicolumn{2}{|c|}{ Excluding Norway and Hungary } \\
\hline & Volatility & $\begin{array}{c}\text { Exchange rate } \\
\text { level }\end{array}$ & Volatility & $\begin{array}{c}\text { Exchange rate } \\
\text { level }\end{array}$ \\
\hline Post & $\begin{array}{l}0.1480 * * \\
(0.0663)\end{array}$ & $\begin{array}{l}-0.0283 * * * \\
(0.0106)\end{array}$ & $\begin{array}{l}0.1739 * * \\
(0.0477)\end{array}$ & $\begin{array}{c}0.0227 \\
(0.0134)\end{array}$ \\
\hline Treat*Post & $\begin{array}{l}-0.1303 * * \\
(0.0428)\end{array}$ & $\begin{array}{l}-0.0394 * * * \\
(0.0146)\end{array}$ & $\begin{array}{l}-0.0914^{*} \\
(0.0533)\end{array}$ & $\begin{array}{l}-0.1223 * * * \\
(0.0112)\end{array}$ \\
\hline Central bank assets & $\begin{array}{l}0.0001^{* * * *} \\
(0.0000)\end{array}$ & $\begin{array}{l}-0.0002 * * * \\
(0.0000)\end{array}$ & $\begin{array}{l}0.0001 * * * \\
(0.0000)\end{array}$ & $\begin{array}{l}-0.1323^{* * * *} \\
(0.0112)\end{array}$ \\
\hline Policy uncertainty index & $\begin{array}{c}0.0001 * \\
(0.0000)\end{array}$ & $\begin{array}{c}0.0470 \\
(0.0496)\end{array}$ & $\begin{array}{r}0.0001 * \\
(0.0000)\end{array}$ & $\begin{array}{c}0.0240 \\
(0.0490)\end{array}$ \\
\hline Intercept & $\begin{array}{l}0.5149 * * * \\
(0.0254)\end{array}$ & $\begin{array}{l}2.7180 * * * \\
(0.0179)\end{array}$ & $\begin{array}{l}0.5149 * * * \\
(0.0264)\end{array}$ & $\begin{array}{l}2.1383 * * * \\
(0.0184)\end{array}$ \\
\hline Adjusted $\mathrm{R}^{2}$ & 0.170 & 0.001 & 0.167 & 0.12 \\
\hline Observations & 4,526 & 4,526 & 4,180 & 4180 \\
\hline No. of groups & 23 & 23 & 21 & 21 \\
\hline
\end{tabular}

Notes. All regressions include fixed country and time effects. Clustered standard errors in parenthesis robust to heteroscedasticity and serial correlation. $* * *, *$ and $*$ indicate statistical significance at the $1 \%$, $5 \%$ and $10 \%$ levels, respectively. 
Table 3

Panel fixed effects results for effective exchange rates

(1) (2) (3)

Dependent variable

Nominal effective

Log of nominal

Log of real effective rate volatility effective rate level rate level

(a) All treatment group countries

Treat*Post

Post

Central bank assets

Policy uncertainty index

Intercept

Adjusted $\mathrm{R}^{2}$

Observations

No. of groups

$$
\begin{aligned}
& -0.1177 * * * \\
& (0.0288) \\
& 0.1369 * * * \\
& (0.0346)
\end{aligned}
$$

$0.0001 * * *$

$(0.0000)$

0.0004

$(0.0003)$

$0.4773 * * *$

(0.0469)

0.151

4,860

23

$$
\begin{aligned}
& -0.0677 * * * \\
& (0.0107) \\
& -0.0290 * * * \\
& (0.0118) \\
& 0.0001 * * * \\
& (0.0000) \\
& 0.0194 \\
& (0.0384) \\
& 4.6097 * * * \\
& (0.0174)
\end{aligned}
$$

\begin{tabular}{|c|c|c|c|}
\hline Treat*Post & $\begin{array}{l}-0.0597^{*} \\
(0.0318)\end{array}$ & $\begin{array}{l}-0.0895 * \\
(0.0521)\end{array}$ & $\begin{array}{r}0.0046 \\
(0.0402\end{array}$ \\
\hline Post & $\begin{array}{l}0.1647 * * * \\
(0.0315)\end{array}$ & $\begin{array}{l}-0.1622 \\
(0.0449)\end{array}$ & $\begin{array}{r}0.0553 \\
(0.037\end{array}$ \\
\hline Central bank assets & $\begin{array}{l}0.0001 * * * \\
(0.0000)\end{array}$ & $\begin{array}{l}-0.0001 * * * \\
(0.0000)\end{array}$ & $\begin{array}{l}-0.000( \\
(0.000 c\end{array}$ \\
\hline Policy uncertainty index & $\begin{array}{c}0.0003 \\
(0.0003)\end{array}$ & $\begin{array}{c}0.01237 \\
(0.03994)\end{array}$ & $\begin{array}{r}0.0123 \\
(0.037\end{array}$ \\
\hline Intercept & $\begin{array}{l}0.4664 * * * \\
(0.0468)\end{array}$ & $\begin{array}{l}-4.6075 * * * \\
(0.0193)\end{array}$ & $\begin{array}{l}4.5988 \\
(0.0136\end{array}$ \\
\hline Adjusted $\mathrm{R}^{2}$ & 0.143 & 0.378 & 0.134 \\
\hline Observations & 4,180 & 4,180 & 4,180 \\
\hline No. of groups & 21 & 21 & 21 \\
\hline
\end{tabular}

$$
\begin{aligned}
& -0.0099 \\
& (0.0082) \\
& 0.0567 * * \\
& (0.0082) \\
& -0.0020 * * * \\
& (0.0000) \\
& 0.0183 \\
& (0.0372) \\
& 4.5988 * * * \\
& (0.0134)
\end{aligned}
$$

0.267

0.199

4,860

23

4,860

23

b) Treatment group excludes Norway and Hungary

Notes. All regressions include fixed country and time effects. Clustered standard errors in parenthesis robust to heteroscedasticity and serial correlation. $* * *$ and $* *$ indicate statistical significance at the $1 \%$ and $5 \%$ levels, respectively. 
Table 4

Panel fixed effects results for bilateral exchange rates (dollar-based)

\begin{tabular}{|c|c|c|c|c|}
\hline \multirow[b]{3}{*}{ Dependent variable: } & (1) & (2) & (3) & (4) \\
\hline & \multicolumn{2}{|c|}{ All NIRP adopters } & \multicolumn{2}{|c|}{ Excluding Norway and Hungary } \\
\hline & Volatility & $\begin{array}{c}\text { Exchange rate } \\
\text { level }\end{array}$ & Volatility & $\begin{array}{c}\text { Exchange rate } \\
\text { level }\end{array}$ \\
\hline Treat*Post & $\begin{array}{l}-0.0999 * * \\
(0.0463)\end{array}$ & $\begin{array}{l}-0.1563 * * * \\
(0.0112)\end{array}$ & $\begin{array}{l}-0.0843 * * \\
(0.0274)\end{array}$ & $\begin{array}{l}-0.1323 * * * \\
(0.0112)\end{array}$ \\
\hline Post & $\begin{array}{c}0.0169 \\
(0.0596)\end{array}$ & $\begin{array}{c}0.0127 \\
(0.0134)\end{array}$ & $\begin{array}{l}0.0903 \\
(0.0840)\end{array}$ & $\begin{array}{l}-0.1768 * * \\
(0.0832)\end{array}$ \\
\hline Central bank assets & $\begin{array}{l}0.0001 * * * \\
(0.0000)\end{array}$ & $\begin{array}{l}-0.1323 * * * \\
(0.0112)\end{array}$ & $\begin{array}{l}0.0001 * * * \\
(0.0000)\end{array}$ & $\begin{array}{l}-0.1343 * * * \\
(0.0000)\end{array}$ \\
\hline Policy uncertainty index & $\begin{array}{l}0.0003 \\
(0.0003)\end{array}$ & $\begin{array}{c}0.0004 \\
(0.0057)\end{array}$ & $\begin{array}{c}0.0005 \\
(0.0008)\end{array}$ & $\begin{array}{c}0.0001 \\
(0.0008)\end{array}$ \\
\hline Intercept & $\begin{array}{l}0.6489 * * * \\
(0.0309)\end{array}$ & $\begin{array}{l}2.3453 * * * \\
(0.0184)\end{array}$ & $\begin{array}{l}0.6434 * * * \\
(0.0310)\end{array}$ & $\begin{array}{l}2.3384 * * * \\
(0.0218)\end{array}$ \\
\hline Adjusted $\mathrm{R}^{2}$ & 0.033 & 0.23 & 0.033 & 0.012 \\
\hline Observations & 2550 & 2557 & 2550 & \\
\hline No. of groups & 23 & 23 & 21 & 21 \\
\hline
\end{tabular}

Notes. All regressions include fixed country and time effects. Clustered standard errors in parenthesis robust to heteroscedasticity and serial correlation. $* * *, * *$ and $*$ indicate statistical significance at the $1 \%, 5 \%$ and $10 \%$ levels, respectively. 
Table 5

Probit estimates of propensity scores for adopting negative policy interest rates

\begin{tabular}{lll}
\hline & $\begin{array}{l}\text { Euro-based, all } \\
\text { countries }\end{array}$ & $\begin{array}{l}\text { Euro-based, excluding } \\
\text { Norway and Hungary }\end{array}$ \\
\hline Inflation & $-0.344 * * *$ & $-0.564 * * *$ \\
& $(0.0640)$ & $(0.0761)$ \\
Unemployment & $-0.237 * * *$ & $-0.286 * * *$ \\
& $(0.0443)$ & $(0.0540)$ \\
Log Central bank independence & $3.476^{* * *}$ & $4.304 * * *$ \\
& $(0.4724)$ & $(0.4745)$ \\
Log Exchange rate regime & $5.060 * * *$ & $7.887 * * *$ \\
Intercept & $(0.7151)$ & $-6.9729)$ \\
& $-3.497 * * *$ & $(0.8306)$ \\
Pseudo $\mathrm{R}^{2}$ & $(0.5503)$ & \\
Observations & 0.372 & 0.460 \\
\hline Robust standar & 1426 & 1252 \\
\hline
\end{tabular}

Robust standard errors in parenthesis. $* * *$ indicates statistical significance at the $1 \%$ level. 
Table 6

Matching estimates of the average treatment effect of negative interest rates on the exchange rate

\begin{tabular}{|c|c|c|c|c|c|c|c|}
\hline & \multicolumn{7}{|c|}{ Matching methods } \\
\hline & $\begin{array}{l}\text { Nearest } \\
\text { neighbor } \\
\text { matching }\end{array}$ & $\begin{array}{l}\text { Three nearest } \\
\text { neighbor matching }\end{array}$ & \multicolumn{3}{|c|}{ Radius matching } & $\begin{array}{l}\text { Local linear } \\
\text { regression } \\
\text { matching }\end{array}$ & $\begin{array}{l}\text { Kernal } \\
\text { matching }\end{array}$ \\
\hline & & & $\mathrm{r}=0.01$ & $\mathrm{r}=0.03$ & $\mathrm{r}=0.05$ & & \\
\hline 1. Bilateral exchange rate volatility, euro- based & $\begin{array}{l}-0.1148^{*} \\
(0.0628)\end{array}$ & $\begin{array}{l}-0.2105^{* *} \\
(0.0944)\end{array}$ & $\begin{array}{c}-0.0656 \\
(0.0631)\end{array}$ & $\begin{array}{l}-0.1438^{* *} \\
(0.0646)\end{array}$ & $\begin{array}{l}-0.1663^{* *} \\
(0.0658)\end{array}$ & $\begin{array}{l}-0.3317^{* *} \\
(0.1158)\end{array}$ & $\begin{array}{c}-0.1779 * * \\
(0.0681)\end{array}$ \\
\hline 2. Bilateral exchange rate level, euro-based & $\begin{array}{l}-0.6254^{*} \\
(0.3348)\end{array}$ & $\begin{array}{l}-0.0996 \\
(0.2189)\end{array}$ & $\begin{array}{l}-0.4437^{*} \\
(0.2635)\end{array}$ & $\begin{array}{l}-0.2702 * \\
(0.1412)\end{array}$ & $\begin{array}{l}-0.1985^{* *} \\
(0.0440)\end{array}$ & $\begin{array}{l}-0.2321 \\
(0.2194)\end{array}$ & $\begin{array}{l}-0.1307^{* *} \\
(0.0469)\end{array}$ \\
\hline 3. Nominal effective exchange rate volatility & $\begin{array}{l}-0.0469 \\
(0.0418)\end{array}$ & $\begin{array}{l}-0.1083 \\
(0.0844)\end{array}$ & $\begin{array}{l}-0.0609 \\
(0.0416)\end{array}$ & $\begin{array}{l}-0.1152 * * \\
(0.0549)\end{array}$ & $\begin{array}{l}-0.1473 * \\
(0.0743)\end{array}$ & $\begin{array}{l}-02575^{* *} \\
(0.1218)\end{array}$ & $\begin{array}{l}-0.1573^{*} \\
(0.0834)\end{array}$ \\
\hline 4. Nominal effective exchange rate level & $\begin{array}{l}-0.0925 * * * \\
(0.0157)\end{array}$ & $\begin{array}{l}-0.1605^{* * *} \\
(0.0412)\end{array}$ & $\begin{array}{l}-0.0985^{* * *} \\
(0.0221)\end{array}$ & $\begin{array}{l}-0.1424 * * * \\
(0.0308)\end{array}$ & $\begin{array}{l}-0.0842 * * * \\
(0.0217)\end{array}$ & $\begin{array}{l}-0.2142 * * * \\
(0.0473)\end{array}$ & $\begin{array}{l}-0.1612 * * * \\
(0.0390)\end{array}$ \\
\hline 5. Real effective exchange rate level & $\begin{array}{l}-0.1478 * * * \\
(0.0192)\end{array}$ & $\begin{array}{l}-0.2100 * * * \\
(0.0559)\end{array}$ & $\begin{array}{l}-0.1548 * * * \\
(0.0258)\end{array}$ & $\begin{array}{l}-0.2062 * * * \\
(0.0385)\end{array}$ & $\begin{array}{l}-0.1356^{* * *} \\
(0.0239)\end{array}$ & $\begin{array}{l}-0.2830 * * * \\
(0.0660)\end{array}$ & $\begin{array}{l}-0.2300^{* * *} \\
(0.0496) \\
\end{array}$ \\
\hline
\end{tabular}

Note: A 0.06 fixed bandwidth and an Epanechinikov kernel are used for kernel and local linear regression matching. Bootstrapped standard errors are reported in parenthesis. ***, $* *$ and * indicate statistical significance at the 1,5 and $10 \%$ levels, respectively. 